MICHAELA PIXOVÁ

\title{
SPACES OF ALTERNATIVE CULTURE IN PRAGUE IN A TIME OF POLITICAL-ECONOMIC CHANGES OF THE CITY
}

\begin{abstract}
PIXOVÁ, M. (2013): Spaces of alternative culture in Prague in a time of politicaleconomic changes of the city. Geografie, 118, No. 3, pp. 221-242. - Cultural plurality distinguishes democratic societies from totalitarian regimes. Cultures that generate low profit are nonetheless constrained by a capitalist economy, which drives them out of spaces available on the market. Some alternative cultures therefore search for spaces that transcend the socio-spatial standards and norms of mainstream society. This paper refers to Marxist urban theory and the concept of the right to the city to demonstrate that in democratic societies alternative non-profit uses of space for cultural purposes are important and create diverse, vibrant, progressive, and socially inclusive urban environments. The example of Prague shows how the changing political-economic context affects spaces that local alternative cultures use. Through observation in the contexts of socialist, post-socialist, and contemporary Prague, the paper aims to examine the inclusivity of the current regime towards cultural plurality, as well as the extent to which the current regime has abandoned the former totalitarian regime's repressive approach towards alternative cultures.

KEY WORDS: urban space - alternative culture - post-socialist city - right to the city Marxist geography - democracy - neoliberalism - urban development - urban politics - civil society.
\end{abstract}

This article was supported by the Grant Agency of the Czech Republic, project GA ČR P404/12/0648 "New socio-spatial formations: segregation in the context of post-communist transformations and globalization".

\section{Introduction}

The aim of my paper is to present the evolution of spaces used by alternative cultures and their position within Prague's urban space. This evolution is discussed in relation to the rest of the society and politics, throughout the fundamental political and economic transformations started by the fall of the former regime in 1989. The spaces used by alternative cultures that this paper focuses on, range from pubs and clubs visited by members of various subcultures, galleries and art centres used by non-conformist artists, to dissidents' secret apartments, unauthorised outdoor parties, political squats, community centres, etc. These spaces, as well as alternative cultures that use them, change with different eras and cultural and political contexts. This paper examines the shift of spaces used by alternative cultures in Prague throughout the transformation, from the undemocratic and oppressive rule of the former totalitarian regime to the contemporary advanced phase of the country's convergence 
towards the global neoliberal order. In post-socialist countries this new order is associated with economic reforms inspired by the policies of the Washington Consensus (Williamson 1990) and the concomitant exposure of these transforming societies to a competitive global market, direct foreign investment, market deregulation, and extensive privatization (Kolodko 1999). These measures were imposed to enhance economic growth, but they have had negative implications for society, such as the dismantling of the welfare state and others. In this new context the city of Prague became subject to the processes of neoliberal urbanism, which Smith (2002) defines as the state abdicating its control over urban development for the sake of market actors and their need to exploit the urban environment for productive capital investments. The research was conducted in an urban environment being reshaped by processes of capitalist urban economy, crippled not only by working on structures inherited from socialism (Sýkora, Bouzarovski 2012), but at the time of the research, also by an ongoing economic crisis, which exerted pressure on investors to employ various socially undesirable practices in order to make profit out of the declining real estate market. Due to the ever increasing imperative of market forces, the conditions for social and cultural reproduction in the city of Prague have been substantially neglected. This troublesome situation provides an opportunity to compare spaces used by contemporary alternative cultures with spaces that served similar purposes under totalitarian rule. The aim of the research is to find out how the forces of contemporary urban development and urban politics influence cultural plurality by means of its affect on the societal and geographic position of spaces used by non-mainstream and non-profit cultures in post-socialist Prague. The driving question to be answered is to what extent do these contemporary processes allow for cultural plurality and inclusiveness that the former regime used to suppress.

So far, neither urban geography nor other disciplines of social science, have sufficiently explored spaces of alternative cultures in the context of post-socialist transformations. It is important to stress that such a context is distinguished by recovering from totalitarian conditions, which were highly repressive towards alternative cultures. At the same time, the downfall of the totalitarian regime was, to a large extent, due to the dissenting activities of the very same repressed cultures. Contemporarily, alternative cultures should be acknowledged as a crucial constituent of a well-functioning democracy and civil society, and their spaces as essential for the production of vibrant, livable, inclusive, and socially just urban environments with zones of creativity and progressive innovations. Nonetheless, despite the alleged democratization, the relationship between alternative cultures and mainstream society remains rather antagonistic; current legal frameworks, authorities, and profit-driven societal standards do not seem to make provisions for the disadvantaged or non-conformist groups and their unconventional ways of securing spaces for their needs. In most cases, the dominant order perceives their practices as unofficial, marginal, and temporary, or deviant, inappropriate and punishable. Various spaces of non-mainstream cultures that operate in non/low-profit ways exist in unequal, insecure, and transient conditions due to the appropriation, displacement, and destruction of urban space propelled by commercial property development and speculations. 
The topic of alternative cultures and their spaces in the city of Prague has recently gained more relevance; similar spaces have become more needed by the civil society undermined by problems associated with the ongoing economic crisis, such as rising societal inequalities and diminishing securities. At the same time, they are being eliminated by expressions of neoliberal urbanism, such as an expanding standardization of the urban environment and a proliferation of various unsustainable forms of development. In Czechia, where democracy is still evolving, the new regime has an opportunity to disavow the practices of the former totalitarian regime by not suppressing or criminalizing cultural plurality and the specific spatial requirements of different cultures. Instead, the regime has an opportunity to contribute to the consolidation of an inclusive and democratic character in our society, as well as to the vibrancy, diversity, and progressiveness of Prague as a city. By increasing its understanding of alternative uses of space, and by embracing and fostering such space in our urban environments, the regime can support trends that lead to a more livable and sustainable city. This paper contributes to this understanding by outlining the most typical forms of urban spaces used by alternative cultures, and by justifying the existence of such spaces in a democratic city through employing the perspective inspired by Marxian urban theories and the theoretical concept of the right to the city. The empirical part of the paper presents the methodological issues of the research performed in Prague, it provides an insight into spatial conditions of alternative cultures in Prague throughout different political-economic contexts, and it evaluates the extent to which contemporary Czech society has achieved democratization in terms of allowing for cultural plurality and purging itself of the oppressiveness and cultural intolerance of the former totalitarian regime.

\section{Spaces and spatial practices of alternative cultures}

According to Marcuse (2009), cities driven by capitalism are not socially just and do not satisfy all people's aspirations and material needs. Many are financially deprived or culturally alienated from such cities due to the highly unequal redistribution of wealth among populations and the prevalence of consumerism (2009). Among the deprived and alienated people we can also find different artists, subcultures, members of NGOs and civil organizations, and students. Such people often are not able to abide by the rules of the dominant order and struggle for suitable spaces for their non-profit and non-conventional cultural activities; spaces commonly available on the market are usually financially unaffordable or unsuitable and unavailable for these kinds of uses. In their search for room for social practices that challenge the hegemonic commercial uses, these people tend to use various non-standard spaces and employ spatial practices that transgress the rules of spatial organization defined by capitalist market forces. However, Merton (1938) points out that the mainstream society is bound by generally recognized goals and standard means of achieving them. Non-conformist use of space might therefore be perceived as abnormal or deviant by the mainstream society. Societies morally and legally push their members to conform, and marginalize those who resist. Alternative cultures 
typically use spaces that stand out from the conventional societal norms, in terms of their legality, politics, appearance, or other non-dominant aspects. The spatial position of such spaces in the city is determined by the extent to which they deviate from the generally recognized rules, norms, tastes, and values of the mainstream society. As we will see in the example of spaces used by alternative cultures in post-socialist Prague, certain cultures are more conformist, and their spaces therefore enjoy a certain tolerance by the mainstream society, e.g. various alternative art centres, galleries, or music clubs, which are allowed to legally operate in temporary conditions in various derelict residual areas, abandoned buildings, or other locations that are not in demand by the mainstream society. On the other hand, cultures, which directly challenge the dominant rule, e.g. autonomous community centres and political squats, face constant attempts to eliminate them.

Due to their specific role in urban development, politics, and economics, the spaces and spatial practices of alternative cultures have received substantial attention from many researchers. Most of the studies of alternative cultures and their spaces have predominantly emerged in West European and North American countries, and tend to focus on their relation to gentrification, urban renewal and development (Clay 1979; Smith 1996; Zukin 1982, 1998, 2010; Florida 2002; Ley 1996, 2003; Cameron, Coaffee 2005), their relation to housing (Kearns 1979, Basu 1988), night-time economy (Chatterton, Hollands 2003), political resistance (Corr 1999; Chatterton, Hodkinson 2006; Hodkinson, Chatterton 2006), as well as urban policies and the image of the city (Uitermark 2004; Pruijt 2004; Shaw 2006). The task of this paper is to investigate and evaluate spaces used by alternative cultures in the context of a city transforming from socialism to post-socialism. The research specifically focuses on the post-socialist period, where the new social inequalities produced in the newly established capitalist society have been developing in an environment affected by socialist legacies (Sýkora 2008, 2009; Sýkora, Bouzarovski 2012), and where alternative cultures struggle for their right to the city through the appropriation of spaces in locations affected by postsocialist urban restructuring.

\section{Spaces of alternative cultures in the capitalist city}

In order to understand the position of alternative spaces in post-socialist Prague we must understand how cities are shaped by capitalism. Besides the undisputable role of cities in capitalist production (Harvey 1973, 1982, 2000, 2001), cities are also key sites of consumption, enabling labour and class reproduction (Castells 1977). Production of urban space plays the key role in contemporary capital accumulation; capitalist urbanization feeds and absorbs the wealth of the ruling class, and cities are therefore undemocratically shaped in a way that reproduces their wealth. The role of people in such cities is that of workers and consumers with an unequal right to affect urban politics or to use urban space for purposes other than those delineated by the imperative of capital accumulation and economic growth (Harvey 2008). According to Harvey $(1973,1982,2000,2001)$, the constantly evolving market system and systematic 
requirement for everlasting growth, including land and property value, create cities controlled by commercial development leading to social inequalities and spatially uneven development.

Harvey $(1989,2001)$ points out that the production of urban space, driven by the circulation of surplus value, often leads to failures and crisis; particularly during economic crisises, some areas get disinvested at the cost of capital centralization elsewhere (Smith 1984). In the context of the neoliberal economy, one of the most common forms of capital centralization is gentrification (Smith 1996), often resulting in the displacement of the socially and economically weaker populations (Marcuse 1985, Smith 1996, Atkinson 2000). Alternative cultures and their spaces sometimes have a specific role in these processes; lower costs drive them to disinvested areas, but their arrival increases the popularity of the area for middle classes, and subsequently attracts investment and enhances new development (see Zukin 1982; Ley 1996, 2003). The developers have learned to take advantage of this process and often actively approach non-conventional creative people, offering them cheap rents in areas where redevelopment is planned (Deutsche, Ryan 1984; Hackworth, Smith 2001). In the end, alternative cultures become displaced themselves by the development they had helped to initiate.

Mainstream discourses occasionally argue that spaces inhabited and used by non-conventional artists feel real and authentic and therefore should be protected from gentrification (Makagon 2010). Such discourses resonate with Florida's (2002) suggestions that cities should take advantage of various cultural productions and creative economies in order to attract the so-called "creative classes" - a specific segment of professionals in creative industries who bring innovation, progress, and economic development to cities (2002). This strategy is opposed by Chatterton (2000), who claims most political attempts to enhance creativity in cities are restrictive towards the true creativity that challenges the social and economic norms, and embeds radical alternatives (2000). "Rebellious" urban forms, such as squats, are usually tolerated or even supported by the city only if they contribute to the city's economic profit, e.g. by attracting tourism (Shaw 2006), or providing social services neglected by the neoliberal government (Uitermark 2004).

Co-opting alternative cultures by the mainstream may lead to their commercialization (Uitermark 2004, Shaw 2006) or cessation (Hodkinson, Chatterton 2006). Inhabiting non-conventional spaces can either challenge or assist the reproduction of capital, sometimes both. The fact that alternative cultures are transient and willing to inhabit derelict buildings and disinvested areas is often exploited in the process of urban development. The city or private owners provide them with spaces that temporarily cannot be redeveloped or be used for commercial purposes. Franck and Stevens (2006) promote the temporary use of spaces during so-called "time-gaps" between former and future use as a way of dealing with rigid urban planning. However, similar practices make alternative cultures dependent on insecure and disadvantageous conditions determined by the interests of development and economic profit. 


\section{The right to the city}

Spaces that alternative cultures use play a key role in satisfying the needs of some people that cannot be satisfied elsewhere and enable the development of civil society. While in totalitarian regimes such spaces are prohibited or subject to strict control, their existence in a democratic society is justified, legitimate, and important. However, the capitalist market condemns cities to function as self-perpetuating machines for capitalistic production, consumption and accumulation, disrespecting the true needs of the citizens, including their need to use spaces for alternative non-profit purposes. Half a century ago, Lefebvre (1967) came up with the concept of the right to the city, which empowers people to affect urban politics and democratically participate in producing and using urban spaces. The right to the city was meant to symbolize a renewed right to urban life in a city where all people, not only the privileged ones, can satisfy a multitude of their human needs and true passions. Lefebvre envisioned a city with a well-defined centre that mainly serves as an inclusive meeting place for all members of the society, and its use value outweighs the value of exchange (1967).

Unfortunately, over time Lefebvre's vision has become even less conceivable. According to Purcell (2002, 2003), the current global neoliberal order disenfranchises citizens by shifting their control over cities, held through democratically elected governments, to unelected transnational corporations and organizations, and the laissez-faire economy (Purcell 2002, 2003). Cities are now dominated by economic elites and their obsession with private ownership and unrestrained capital accumulation. On that account, Harvey says that freedom in cities is only illusionary and blends with the freedom to consume (Harvey 2008). People deprived or alienated from consumption and commodified urban spaces cannot but reclaim their right to the city through resistance and subversion (Chatterton, Hollands 2003; Mitchell 2003). The idea of radical popular struggle over the right to the city has therefore also infiltrated into many world-wide social movements and resulted in the creation of the "World Charter on the Right to the City", an initiative that addresses the problems of contemporary urbanization and its impact on urban populations, as well as a platform for worldwide efforts towards the recognition and legal enforceability of the right to the city as a new kind of human right (see Brown 2010). The right to the city can entail the right to inhabit and use the resources of the city by all members of the society, be it in the form of building informal settlements, squatting vacant property, establishing social and cultural centres in underused buildings, or various other alternative ways that deviate from the generally recognized standards.

\section{Methodological remarks}

The results presented in this paper were assembled as part of my dissertation research, which examined the spaces used by alternative cultures in Prague over approximately the last four decades, an era that adequately delimits the most turbulent changes in the political and economic contexts of these spaces. 
The scope of this paper covers only part of my dissertation research, and its focus is specifically confined to outlining the way in which the transformation from socialism to post-socialism influenced the location and character of spaces used by alternative cultures in Prague, and to the assessment of the contemporary regime's acceptance and inclusivity towards cultural plurality. The results of this paper are drawing from the data collected and analysed by means of qualitative research methods, which were employed with respect to the exploratory nature of the whole dissertation research, as well as respecting the different eras of the observed spaces. Retrospective research of spaces that no longer exist or spaces that served alternative cultures at the time of the research were, clearly, different from the research of spaces that are used by alternative cultures contemporarily.

I. Spaces used by alternative cultures during totalitarian socialism, specifically the era of normalization, are documented relatively extensively in literature, various documents, and media. Apart from drawing from these sources I also employed an adapted method of oral history, which I collected 1) in the form of semi-structured interviews conducted with ten narrators, 2) in the form of questionnaires with open questions filled in by six respondents, and also 3) in the form of numerous informal interviews conducted with various witnesses of the era. The narrators and respondents were predominantly people associated with music subcultures and countercultures, or dissenting artists and authors that lived in Prague in the 1970s and 1980s. The collected data served for the creation of an overview of the most significant spaces used by alternative cultures in socialist Prague (illustrated by Fig. 1), and for explaining the overall character and geographic location of these spaces, as well as their relation to the totalitarian socialist rule.

II. Spaces used by alternative cultures in post-socialist Prague were researched by methods inspired by ethnographic approaches, which are useful for human geography thanks to their effectiveness in "uncovering the processes and meanings that undergird socio-spatial life" (Herbert 2000, p. 550). In order to reveal deeper systemic patterns, I employed a multilocale ethnographic research, which according to Katz (1994), should be performed in two or more sites that, at least on the surface, are not alike (Katz 1994, p. 68). As a long-time member of Prague's alternative scene I could draw on longitudinal participant observations in all studied spaces, and on extensive social networks. From the position of an insider, I employed the triangulation of methods (see Deegan 2001), which included monitoring and analyzing various documents, media coverage related to political decision-making and urban development, as well as the cultural politics of the city, extensive field work, everyday interactions with study subjects, and interviews. I conducted 30 semi-structured interviews, out of which six were conducted via email, and many informal interviews. Interviewees consisted of squatters, anarchists, musicians, activists, creative professionals and artists, art curators and managers, sponsors and philanthropists, politicians, innkeepers, and supporters of alternative culture. Each interviewee was questioned about the particular space they were involved with. Questions focused on the way these spaces had been acquired, restored, operated and financed. I was interested in which way each space served cultural purposes, as well as in their downsides and advantages in terms of their 
geographic location, accessibility, financial affordability, popularity among the public, and the relationship of the keepers with the property owners, local community, municipal as well as local politicians, and various sponsors. Some interviews also included a discussion about the changes in nature and meaning of alternative culture throughout different economic and political eras in Prague. A deeper analysis and interpretation of this phenomenon would require a separate study; nonetheless, it allowed me to identify certain processes that influenced the nature and spaces of alternative cultures in Prague during and after the transformation from socialism to capitalism.

The collected data was subjected to political-economic analysis, which primarily focused on the limitations that alternative cultures face in terms of finding and using space in post-socialist Prague, as well as interacting and negotiating with the authorities, developers, and the general public. These findings were used to outline how social structures on a global, national and municipal level impact the existence and positions of spaces used by alternative cultures in post-socialist Prague (see Figure 2 and Figure 3), and were compared to the situation of alternative cultures in Prague under totalitarian rule. The main limitation of such an interpretation is personal participation of the researcher in alternative culture. Due to this involvement, factors that stem from the hegemonic modus operandi that play against the existence of alternative culture in the city, such as the imperative of capital accumulation or private property inviolability, are bound to be subject to critical scrutiny.

\section{Spaces of alternative cultures in a changing political-economic context}

When researching spaces used by alternative cultures in socialist and postsocialist Prague, we must consider three different contexts; the two distinctively different regimes, as well as the anomalous context of transformations during the country's transition between two regimes.

Alternative cultures, and the spaces they have used in each one of the three political-economic contexts, have distinctive characteristics. Alternative culture is not unchanging, it is an ephemeral phenomenon. Each era has fringe cultures that constitute alternatives to the dominant culture. With new trends in the society and culture, as well as different political and economic contexts, cultures considered alternative also keep changing. Some of them, especially the so-called countercultures, may challenge the ideological integrity of the society. The nature of the regime and of the alternative culture, as well as their mutual relationship, determines the spaces that alternative cultures use within the city.

Under totalitarian socialism, the planning of the city of Prague stemmed from the priorities of the Communist Party, and resulted in the creation of a specific type of socialistic inequalities (Sýkora 2009). Ideological supervision oppressed and prohibited all activities, cultures and civil society which were deemed unsuitable for the official culture promoted by the regime (Vaněk et al. 2002). Pursuers of alternative culture interviewed for the purposes of this project used to socialize privately in their own homes or outdoors, especially in 


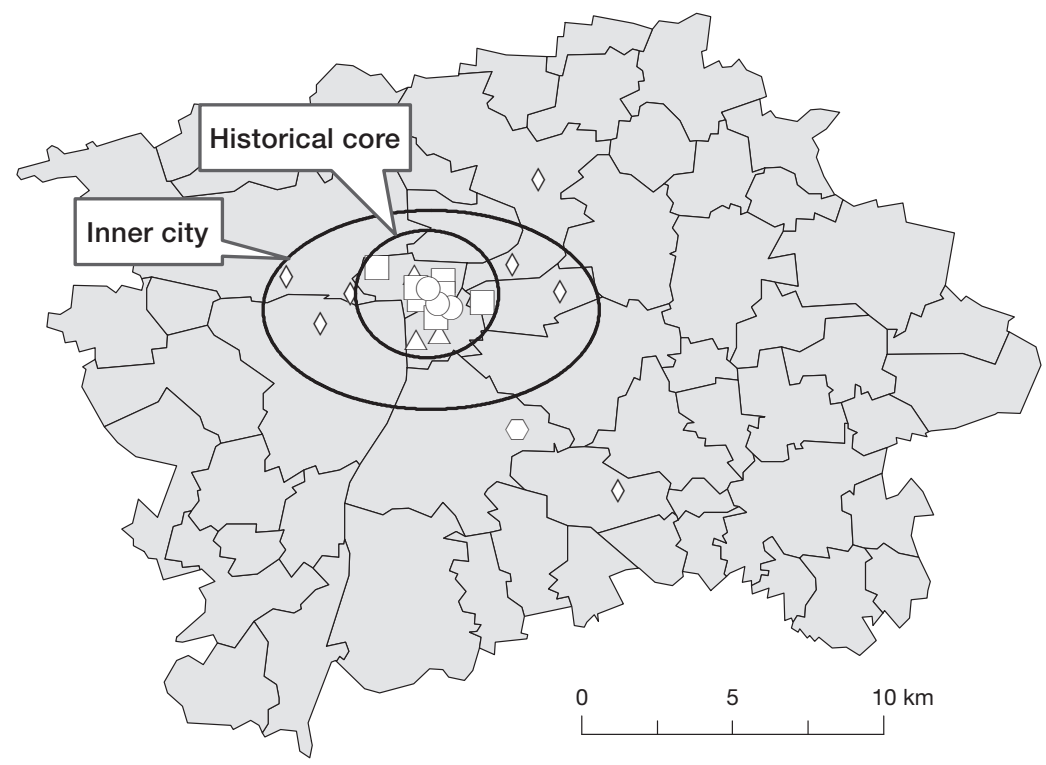

private apartments

pubs

cultural centers

Jazzová sekce (The Jazz Section)

outdoor sites

Fig. 1 - Spaces used by alternative culture in socialist Prague (1970s-1980s)

parks, subway stations, or near various monuments and important buildings, such as the National Museum. They also socialized in pubs and restaurants that tolerated their presence. The geographic location of alternative cultures in socialist Prague was not determined by the market, but mainly by the pursuers' need to remain unnoticed by the authorities. Paradoxically, as obvious in Figure 1, pursuers of alternative culture in socialist Prague tended to concentrate in the city centre, which was relatively affordable, had the biggest density of pubs, and provided certain anonymity. Concerts of alternative music were on the other hand either held outside of the city - in the countryside, where the control of the regime was lower - or by means of various concealing and semi-official practices in official cultural centres within recreational facilities across Prague's post-war residential neighbourhoods. With the exception of occasional concerts, these peripheral areas were mostly avoided by the pursuers of alternative cultures, as they provided a low chance of meeting other peers. Other areas to be avoided included industrialized zones around the historic core, which were still operational and provided no suitable vacancies for cultural production. One sought after location was the headquarters of Jazzová sekce (The Jazz Section), an official organization of jazz music supporters, who had access to music from abroad; they disseminated ideologically undesirable music recordings to the public and organized uncensored concerts featuring local alternative musicians. It was abolished by the regime in 1984 . 


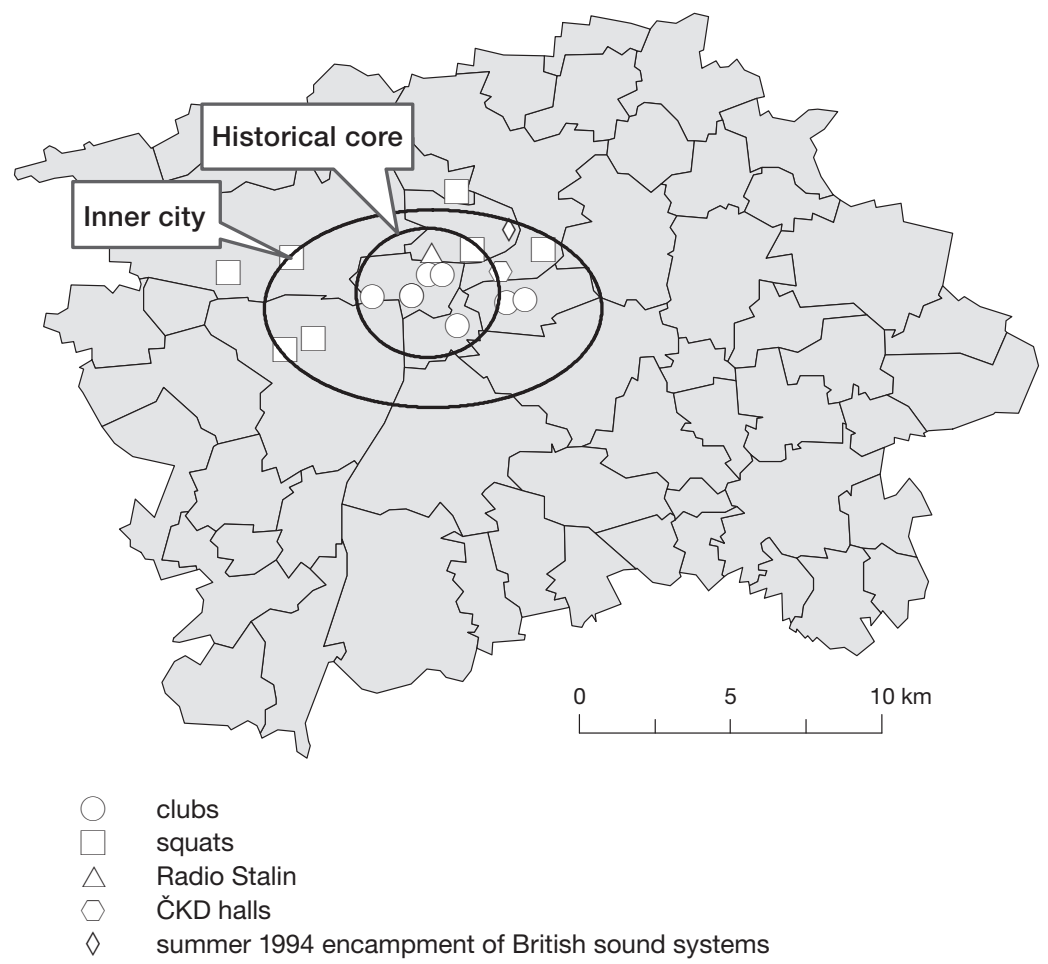

Fig. 2 - Spaces used by alternative culture in Prague during early transformation

After the Velvet Revolution in 1989, totalitarian socialism was transformed into democratic rule, and the centrally planned economy into a free market. Prague became a fluid and unstable zone defined by a multitude of uncoordinated processes of societal transformation, accompanied by impetuous urban restructuring consisting of property restitutions, privatizations, rent-deregulations, and spontaneous development on unused land. State-owned property underwent restitution or came under municipal ownership. Politicians dealt with institutional reform and new legislation, the former cultural dissent abandoned its oppositional stance, and people openly experimented with new possibilities.

In the $1990 \mathrm{~s}$, civil society started to awake, and spontaneous activities in the city were temporarily tolerated. Previously restricted or prohibited cultures started to form a new layer of urban spaces; new clubs, cultural centres, and other types of spaces and spatial practices. As obvious from Figure 2, many spaces for alternative culture were formed in the historical core and the inner city; people kept concentrating in this area just like during the former regime. The area was full of abandoned theatres, ballrooms, or antinuclear shelters, often used as provisional storages. Cultural enterprises such as Roxy, Rock Café, Bunkr, or Radost FX were built in such spaces during the transformation. Other groups attempted to introduce the phenomenon of squatting, occupying vacant buildings in different areas of the city; the squatted farm estate Ladronka in the city district of Prague 6 gained international significance. 


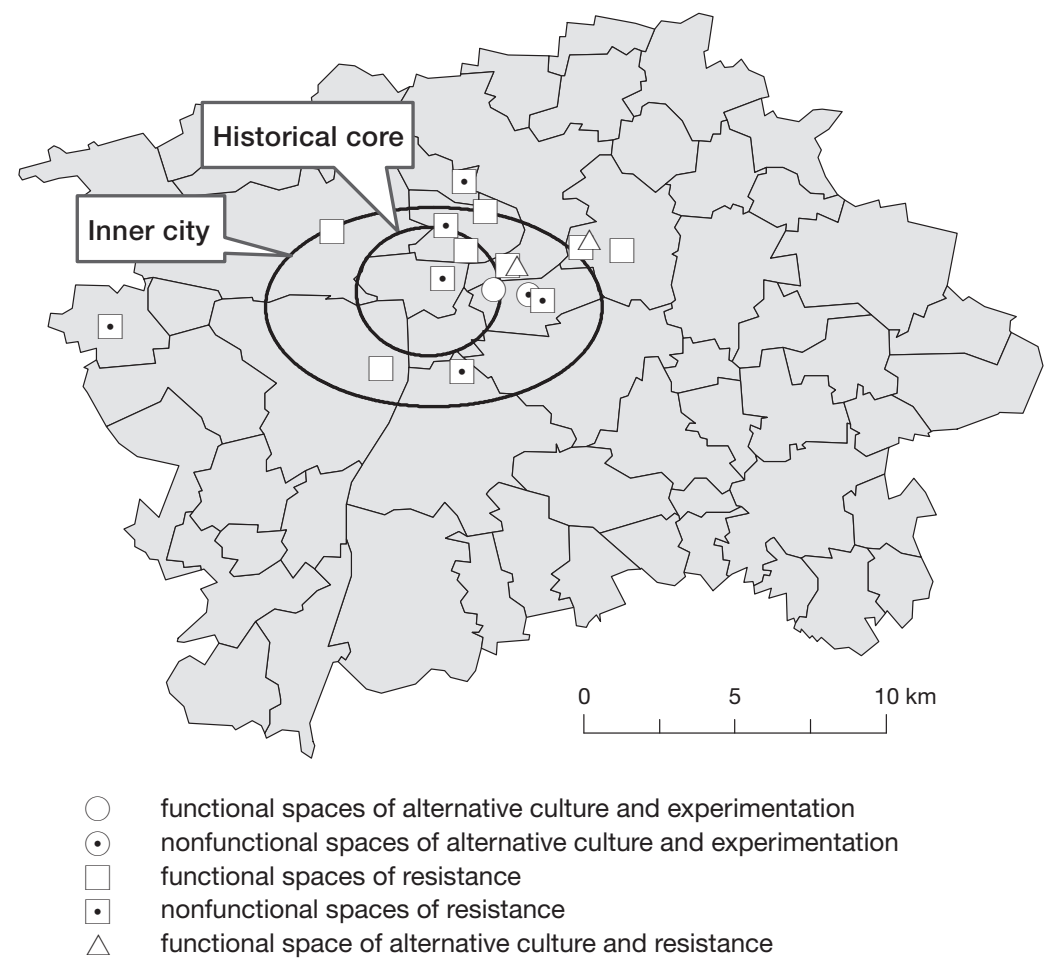

Fig. 3 - Spaces of alternative culture in the context of neoliberal urbanism

Freed from the former regime and so far unspoiled by capitalism, Prague also attracted various free-spirited pursuers of alternative culture from abroad, e.g. the legendary nomadic sound systems from Great Britain, Spiral Tribe and Mutoid Waste Company, which introduced the Czech youth to a new type of electronic music and the phenomenon of illegal free parties held outdoors or in abandoned warehouses, such as in the ČKD halls in the Karlín neighborhood.

Witnesses to this early transformation say that most cultural trends newly imported from abroad were rather experimental, marginal and unspoiled by commerce. Some of the newly founded cultural spaces, including the centrally located ones, had a relatively independent and edgy atmosphere during the early beginnings. Closer to the end of the first democratic decade, the short era of spontaneity and freedom in Prague started to crumble. Most squats were evicted and some popular clubs in the city centre, such as Bunkr or Propast, were violently closed down. Organizing unauthorised parties started to be more suppressed by the authorities. Much of the violent action towards spaces used by alternative cultures, alongside the first notions of the club scene's commercialization, corresponded with the progressing completion of the country's transformation. The almost complete institutional reconfiguration, followed by the gradual consolidation of the new socio-economic order, became increasingly shaped by the imperative of global capitalism, evident in the form of neoliberal urbanism. 


\section{Spaces of alternative cultures in the context of neoliberal urbanism}

After the turn of the millennium, most institutional reforms had already been completed and a new social order had come to force. Most property was by then privately owned, and the number of available spaces or disinvested and underused land in the city was diminishing, as were the spaces for culture and activities which were slowly starting to be squeezed out by economically more profitable activities in the city. Prague was rapidly approximating the standard practices of the developed capitalist societies in terms of rising corporate and state control over the city's nightlife economy and cultural production (Fig. 3). Inner city areas became lucrative gentrification hotspots, hostile towards alternative and unprofitable uses of space. Many clubs in central parts of the city founded during the preceding period started to be restricted by new regulations, generally working to protect private owners, private ownership, and private profits. Some of them became more mass-culture oriented and commercialized, losing their independent and edgy atmosphere. Others had to shorten the duration of their production to avoid peace disturbances at night or ceased to exist. The last illegal reminders of alternative spatial practices, especially squatting, were gradually banished and forced to operate in semilegal ways. With rising property prices, even artists started to find it increasingly difficult to finance their art studios and searched for cheaper locations. In general, Prague's alternative culture of the $21^{\text {st }}$ century's first decade was distinguished by it gradually leaving the city centre and moving further to the periphery of the city. Different alternative cultures were exposed to these new limitations and restrictions in different ways, and how they reacted to them was different as well. Most tried to negotiate and cooperate with municipal or private owners of vacant properties, compromising many of their requirements, expectations and beliefs. The way two groups with a very distinct approach towards alternative culture (one that is embedded in the societal status quo and one that resists and opposes it) experienced their struggle for the right to the city, are outlined below.

\section{The non-resistant spaces of alternative culture and experimentation}

The period between the years 2005 and 2012 became especially fruitful in the emergence of new artistic and cultural initiatives claiming their right to the city by occupying former industrial zones with brownfields undergoing gentrification. At a certain point, various companies that owned and redeveloped property in these areas began facing various constraints, and decided to sell, or commercially utilize part of their undeveloped property. Some of them offered their vacant property as art studios for artists. In other cases, students or cultural events' organizers approached property owners and negotiated the rental of their property.

In this way, a former electrical transformer station in Libeň became home to Trafačka, a still operational complex of art studios and galleries featuring 
occasional art shows and low-profile experimental music concerts. A former maintenance warehouse for trucks in the same area turned into Hala C, a space for various non-profit projects and activities, cultural events and socializing. In 2010, after a period of three years, Hala $C$ ceased to exist due to commercial redevelopment. In Karlín, a former factory complex $\check{C} K D$ became home to the projects Karlín Studios and Hala Thámova. The first one still serves as a collective art studio with occasional art shows and cultural events. The later was a huge industrial space occasionally provided by the owner for different cultural events. In 2012, the hall underwent redevelopment and stopped serving the same purpose. Another interesting contemporary project is Bubenská, established in a heritage office building from the 1930s, which the developer now rents out to artists for reduced rent due to a lack of interest from wealthier clients. Two cultural projects, MeetFactory near the railway station in Smíchov, and Klubovna - a former nursery in Dejvice, were founded in municipally owned buildings. While Klubovna is a small independent student club focused on youth culture, which initially faced strong opposition from the local $\mathrm{Mu}$ nicipality, MeetFactory turned into a huge cultural project heavily subsidized by the city, mainly due to personal connections between some of MeetFactory's key artists and local politicians.

Lacking other possibilities, the initiators of all the above mentioned projects agreed to temporarily use vacant spaces in exchange for assisting the economic interests of particular owners, either private or municipal. Instead of fully claiming their right to the city, they accepted the fact that their cultural activities could not be pursued in commercially rented properties, for the most part because of their non-profit character and the volume of space they required. As a result, they agreed to a temporary and insecure role as unpaid custodians of buildings, which would otherwise remain abandoned, dilapidating further until their destruction or redevelopment for commercial purposes: “... they (Karlín Real Estate Group) are glad that we are there, they have at least some money, each building disintegrates less when it is used rather than empty ... It's simply a temporary experiment, if it lasts for ten years, it is still a nice thing. The deal with the owner was clear. I cannot fight and refuse to leave, and make them evict us..." (Alberto di Stefano, member of the civil organization Karlin Studios). Most of the non-resistant users of vacant spaces acknowledged that property owners profit from having their spaces rented out for cultural purposes, but at the same time displayed appreciation at their willingness to provide their property for purposes that generate little profit. The pressing situation on the real estate market in Prague forced most of these users to agree to almost any kind of barter, usually neglecting the fact that it should be the owners' responsibility to take care of their property. The non-resistant users did not intend to resist the owners' future plans with their property, despite the fact that they had invested significant sums of money into the upkeep of these vacant spaces: "We did everything with our own hands; we fixed the electricity, installed a new water supply, made a new sewer" (Jan Špinka, Klubovna). Most of them also appreciated the aesthetics of old industrial buildings, and regretted the general tendency towards their standardization and commercial rehabilitation: "I really like these spaces that used to be something completely different, and I like giving them a new meaning. I used to for example organize 
events in sewage plants. The building does not have to decay - it can be used for something else. It has its own atmosphere - you are working with it, the lights, installations... You are not restricted by any institution, it's a free space" (Omri Goz, organizer of cultural events at Hala C). However, none of them were willing to openly challenge these processes.

The fact that some of the above listed spaces used by alternative cultures have survived until today is mainly due to the global economic crisis, which started to affect real estate development in Prague in 2008. Development slowed down and companies began having financial problems. In particular, the users of Trafačka explicitly acknowledged the prolongation of their cultural project due to a time-gap that the economic crisis had created in between the former and future use of the property: "If Trafačka was located in Shanghai, we would most likely get evicted within a month, and in half a year something completely different would get built here. Despite the fact that our destiny is clearly determined from the beginning, we believe in crisis... What can we do?" (Jakub Nepraš, artist from Trafačka). The same time-gap also gave rise to the Bubenská project, a space that was originally intended for purposes of high-end commerce. Artists and other creative professionals who are renting out the building's premises instead of wealthier clients also operate in insecure and temporary conditions: "Of course, if richer clients want to lease the offices, they will be given priority" (Šárka Thérová, Orco leasing coordinator). Despite public subsidies, insecurity strikes even MeetFactory, as the old industrial building is hard to keep operational and subsidies from public resources cannot be used as investment. MeetFactory therefore cooperates with commercial subjects in order to finance its own existence, gradually blending with the mainstream culture and losing its alternative character. Other projects, such as Karlin Studios, Trafačka, or Klubovna, have always been pre-destined to cease or to move further to the periphery in the future.

Despite the hardship associated with using vacant spaces in a non-profit alternative way, and the authorities' obvious neglect of policies that would ensure better conditions for the non-commercial culture in the city, the users of the above mentioned projects generally display little interest in taking a more pro-active attitude towards challenging the hegemony of economic interests over Prague's urban development. Artists, students, and various creative professionals are mostly convinced that alternative and non-profit culture is important for society, and they are aware of the fact that commercial development and overemphasizing economic interests of the elites are destroying this culture. Nonetheless, most of them prefer to comply with the status quo. This non-oppositional stance on the other hand ensures them a better bargaining position with private owners and the authorities, who are in turn more willing to let them use vacant properties. This trend should be further fostered, and institutionalized in a way that also benefits the users, not only the economy and the owners of vacant property. Eventually, new policies that ensure a better use of underused properties may benefit even those groups that are in sharper opposition to the status quo. 


\section{Spaces of resistance}

In most Western cities, alternative cultures can be found that oppose the status quo of the capitalist society - the so-called countercultures. They establish squats, social centres, infocafes and infoshops, and other spaces that challenge the frameworks delineated by societal structures that these countercultures oppose. Their spaces are usually short-lived because the dominant society neither supports them nor approves of them. Anticapitalist countercultures often claim their right to the city by trespassing, and pursue activities that the dominant order regards as unlawful and undesirable. They struggle when compelled to operate in spaces where they have to pay market rent.

Across Europe and North America, authorities, as well as the dominant society, perceive these resistant countercultures differently depending on the overall context. In Czechia, unlike for example in Spain, the UK, or the Netherlands, countercultures such as squatters or anarchists exist, but have not yet been sufficiently entrenched. The Czech society, whose experience with the capitalist order is still relatively short, mostly perceive these groups as threatening and undesirable: "In the west people were failed by capitalism a lot earlier than people here, we have just started being failed now. Abroad nobody cares if you are a squatter, as long as you don't mess around" (anonymous squatter). People in Czechia refuse to accept alternative approaches towards securing one's right to the city, e.g. by illegal, although legitimate occupations of underused buildings. Moreover, Czech legislation never recognized squatting as a form of housing and still considers it illegal (Růžička 2006). In Prague, the authorities quickly banish any unauthorized use of abandoned buildings for cultural purposes, sometimes by means of violent force. The relatively marginal phenomenon of squatting received elevated attention from the public in June 2009 due to a violent eviction of the final remaining political squat, Milada. The squatters were surprisingly offered a temporary shelter in a semi-vacant residential building on Truhlářská Street, owned by Petr Svinka. The widespread suspicion was that in order to pursue his commercial plans for the building, Svinka attempted to banish the remaining tenants by exposing them to people perceived as dangerous misfits. Local authorities and the media criticised Svinka for helping "the undesirables", while threatening "normal" people. The situation evolved unexpectedly; the squatters unified with the tenants against Svinka and his displacement practices: "The squatters really unified us as tenants. We had already been unified in our fight against Svinka, but the squatters really consolidated us" (Milan Smrž, tenant in the house inhabited by squatters). In the end, the tenants experienced the squatters as creative and helpful young people with a negative label given to them through the dominant discourse. The two groups cohabited in symbiosis for a year, and their mutual cooperation proved to be a viable, although short-lived way of securing their right to the city.

During the same year, the squatters searched unsuccessfully for a new place they could relocate to. In September 2010, they organized a happening during which they demonstratively occupied an abandoned spa in the historic centre, trying to highlight the problem of idle vacant space and property speculation in a city where rents are increasingly unaffordable. The occupiers were arrested 
by the police and endured a lawsuit, which lasted a year and half before being acquitted. In autumn 2010, a few squatters relocated to a warehouse on the brownfield of a former freight station in Žižkov. In this space they joined a newly established anarchist infoshop called DIS Centrum. Having to pay rent, the squatters' energy was invested into for-profit activities and culture, which became unsustainable due to their inability to pursue any non-profit activities. Resulting illegal attempts to start squat projects elsewhere were suppressed by the police. Finally, in spring 2012, a section of the squatters joined up with the civil organization A2 and their initiative Oživte si barák (Enliven Your House), aimed at raising awareness of the number of abandoned historical buildings in Prague. The two groups managed to gain permission to use a dilapidated historical mansion in Košíre, known as Cibulka, for cultural purposes. Its owner, a private travel agency called Autoturist, granted the permission mainly because the local community and the conservationists had heavily criticized the agency for neglecting the property. Nonetheless, it remains unclear how long the arrangement will last. The historical building is falling apart fast and the squatters lack resources for its upkeep.

Sometimes resistant opposition occurs even among apolitical alternative cultures. A special struggle for the right to the city occurred in the case of Parukářka pub in Žižkov. Built by the current owners in 1995, the dive bar is surrounded by a park where people can picnic and take in a view of the whole city. It is popular with the local community, old rockers, alternative youth, dog walkers and families. Different cultural events, including many alternative ones, are held there. However, future prospects of the pub have been affected by the animosity of local authorities. It operates in a semi-official way, as the authorities refuse to grant it a permanent building approval. Due to new residential development nearby, the park might experience an influx of new, affluent inhabitants. Local politicians have recently tried to vacate the pub, and replace it by a new luxurious restaurant: "For 10 years they left me alone, and then some councillor checked it out here and probably thought - 'why should this guy have this spot, would be better to keep the spot to myself or to my friends'..." (Gregůrek, innkeeper). Patrons of Parukářka hold that the local authorities are convenient to the developers and profit from mediating their interests in the area. This scenario has nonetheless recently changed; protests and petitions were held against the pub's removal, development slowed down due to economic crisis, and local authorities were replaced by their opposition. According to M. Stropnický, the new vice-mayor of Prague 3 and a Green party member, there are fewer incentives to build a new restaurant due to lack of people interested in buying property in a nearby gated community. Thanks to the support of the current political leadership in Prague 3, and owing to its relatively strong potential to mobilize the local community, Parukářka is likely to survive at least until the next elections.

Despite the partial success of resistant alternative culture during the most recent economic crisis, the future of similar projects remains unclear. In Prague, the most resistant countercultures remain rather isolated and their spaces pre-destined to an uncertain temporary existence. Their continual hardship is associated not only with economic pressures and their ability to comply with the current legal system, but also with local authorities' animosity and the many 
prejudices and fears of mainstream society. However, the case of Parukářka and the squatters' activities in Truhlářská Street show that outreach and establishing alliances with other interest groups and local communities can potentially earn alternative uses of vacant space legitimacy in the eyes of the mainstream society, and allow the pursuers of alternative cultures to procure their right to the city. Ultimately, the ill-reputed alternative cultures could also be more pro-active in gaining control over the message that the dominant society receives about them. By moving beyond their often narrow self-interests and cooperating with other groups that are marginalized or disenfranchised by various aspects of neoliberal urbanism, they could gain more support and encouragement for their alternative projects among the mainstream society.

\section{Summary and critical evaluation}

In regards to spaces used by alternative cultures in Prague before and after the Velvet Revolution, the research has shown that the country's transformation from totalitarian socialism to contemporary capitalism has not only resulted in many significant changes, but also retained some path-dependencies. Figures 1, 2 and 3 illustrate the obvious gradual shift of spaces used by alternative cultures from the historical core towards the former industrial production zones on the edges of the inner city, mainly caused by the economic pressures that arose in the centrally located areas upon the imposition of a market economy. At the same time, the character of alternative cultures and countercultures has changed due to the country's openness towards quickly changing trends abroad, as well as the different character of the new regime. What has not changed, and has displayed certain path-dependencies, are the approach of the authorities and the mainstream society towards alternative cultures and their alternative use of space. The approach has remained rather prejudiced, uninformed, intolerant, and ultimately undemocratic. From the perspective of Marxian urban theory, it is obvious that alternative cultures in Prague keep being pushed into conformity with the dominant society and the market-driven ways of using urban space. They may no more face outright persecution for ideological reasons, but they still lack the right to the city which would ensure them space for their non-profit activities without forcing them to comply with unaffordable property prices and the imperative of commercial urban development.

There is no doubt that the existence of alternative cultures in Prague is very important, as it brings diversity, vibrancy, innovativeness, and grassroots activities to the city. Furthermore, it consolidates democracy and a civil society that long suffered under the totalitarian rule. Current conditions, however, continually undercut the existence of such virtues in the city. The imperfections of post-socialist transformation are potentially leading to yet another assault on alternative cultures, which could negatively affect the continuing evolution of civil society and democracy in Prague. Due to the dogmatic acceptance of neoliberal urbanism and the value of indefatigable private ownership, which is not dissimilar to the dogmatic embracement of Moscow's dominion before the Velvet Revolution, the amount of available spaces for alternative cultures in Prague is decreasing and their alternative use becoming increasingly more 
limited and restricted. This is reinforced by the absence of historical experience with socio-economic inequalities and more diversified populations among the mainstream society, which further isolates alternative interests from the dominant discourses.

The approach of the municipal and private actors towards alternative cultures in need of space is twofold: it is either 1) mercantile - exploiting alternative cultures' needs and unequal societal position to benefit their own economic needs and interests; or it is 2) restrictive and oppressive - it delegitimizes alternative cultures that challenge the status quo, and eradicates them from urban space. Both approaches stem from the dogmatic protection of private economic interests and the neglect of social and cultural reproduction that generate little or no profit. Alternative use of vacant properties might be preferred only during development stagnation and the owners' financial problems. At the same time, alternative use might also be feared due to some alternative cultures' open opposition towards a status quo based on economic growth and private ownership. While artists are willing to operate in the unequal, insecure and transient conditions of quickly gentrifying areas of former industrial production, playing the role of unpaid custodians who upkeep and restore the property at their own expense, cultures that challenge the status quo such as anarchists and squatters are excluded from similar deals. The approach that authorities employ against the unauthorised use of vacant property by resistant cultures is often violent and not dissimilar to oppressive practices used against alternative cultures under the totalitarian regime in former Czechoslovakia.

It is time for post-socialist Prague to fully overcome the shadows of its past. To wake up to the fact that the illusion of capitalism as a non-ideological system which allows for the freedom of diversity and new alternatives is false; conditioning alternative cultures by their commoditization and conformity leads to their gradual destruction and the loss of their innovative and progressive potential. In other words, along with the change of regime alternative cultures should be finally granted their right to the city. A viable solution to this problem is to strengthen the resistant groups' cooperation with members of the mainstream society who are affected in various ways or outraged by the current form of capitalism and neoliberal urbanism, and who also lack their right to the city. If such cooperation is combined with profound changes in urban policies and legislation concerning the usage of vacant underused property, which non-resistant alternative cultures may potentially be successful at lobbying for (if more pro-active), there is still a chance for viable solutions to ensure the right to the city for the resistant cultures, along with the citizens threatened by social exclusion, for the enhancement of democracy and civil society through the support of grassroots activities and community development, as well as the enrichment of Prague's creative industries and touristic potential by improving the conditions for new cultural trends. By embracing alternative uses of urban space, including spaces that are centrally located, without exploiting, marginalizing or repressing the alternative users, the city of Prague has a chance to develop exciting and liveable urban environments with a culturally diverse society that finally abandons the practices and attitudes that stem from the legacies of the former totalitarian intolerance towards cultural plurality and non-conformity. 


\section{References:}

ATKINSON, R. (2000): The hidden costs of gentrification: Displacement in central London. Journal of Housing and the Built Environment, 15, No. 4, pp. 307-326.

BASU, A.R. (1988): Urban Squatter Housing in Third World. Mittal Publications, Delhi, $316 \mathrm{pp}$.

BROWN, A. (2010): The 'Right to the City': from Paris 1968 to Rio 2010. Accessed Nov-11-2011: http://www.n-aerus.net/web/sat/workshops/2010/pdf/PAPER_brown_a.pdf.

CAMERON, S., COAFFEE, J. (2005): Art, Gentrification and Regeneration: From Artist as Pioneer to Public Arts. European Journal of Housing Policy, 5, No. 1, pp. 39-58.

CASTELLS, M. (1977/1972): The Urban Question. A Marxist Approach. Edward Arnold, London, $502 \mathrm{pp}$.

CHATTERTON, P. (2000): Will the real Creative City please stand up? City, 4, No. 3, pp. 390-397.

CHATTERTON, P., HODKINSON, S. (2006): 'Why we need Autonomous Spaces in the fight against Capitalism'. In: Bryan, K., Chatterton, P., Cutler, A. (2006): Do It Yourself: A Handbook for Changing our World. Pluto Press, London, pp. 201-215.

CHATTERTON, P., HOLLANDS, R. (2003): Urban nightscapes: youth cultures, pleasure spaces and corporate power. Routledge, London, $304 \mathrm{pp}$.

CLAY, P.L. (1979): Neighborhood renewal: Middle class settlement and incumbent upgrading in American neighborhoods. Lexington Books, Lexington, MA, 114 pp.

CORR, A. (1999): No Trespassing: Squatting, Rent Strikes and Land Struggles Worldwide. South End Press, Cambridge, 244 pp.

DEEGAN, M.J. (2001): The Chicago School of Ethnography. In: Fine, G.A. (ed.) A Second Chicago School? University of Chicago Press, Chicago, pp. 322-364.

DEUTSCHE, R., RYAN, C.G. (1984): The Fine Art of Gentrification, The MIT Press, 31, pp. 91-111.

FLORIDA, R. (2002): The Rise of the Creative Class: And how it's transforming work, leisure, community and everyday life. Perseus Book Group, New York, 416 pp.

FRANCK, K.A., STEVENS, Q. (2006): Loose Space: Possibility and Diversity in Urban Life. Taylor\&Francis, Abingdon / New York, 320 pp.

HACKWORTH, J., SMITH, N. (2001): The changing state of gentrification. Tijdschrift voor economische en sociale geografie, 92, No. 4, pp. 464-477.

HARVEY, D. (1973): Social Justice and the City. Edward Arnold, London, 356 pp.

HARVEY, D. (1982): The Limits to Capital. Blackwell, Oxford, 478 pp.

HARVEY, D. (1989): The Condition of Postmodernity. An Enquiry into the Origins of Cultural Change. Blackwell, Oxford, 378 pp.

HARVEY, D. (2000): Spaces of Hope. Edinburgh University Press, Edinburgh, 293 pp.

HARVEY, D. (2001): Spaces of Capital: Towards a Critical Geography. Routledge, London, $429 \mathrm{pp}$.

HARVEY, D. (2008): The Right to the City. 'New Left Review', http://abahlali.org/files/Harvery_right_to_the_city.pdf, pp. 23-40 (8.11.2011).

HERBERT, S. (2000): For ethnography. Progress in Human Geography, 24, No. 4, pp. 550-568.

HODKINSON, S., CHATTERTON, P. (2006): Autonomy in the city? Reflections on the social centres movement in the UK. City, 10, No. 3, pp. 305-315.

KATZ, C. (1994): Playing the Field: Questions of Fieldwork in Geography. The Professional Geographer, 46, pp. 67-72.

KEARNS, K.C. (1979): Intraurban Squatting in London. Annals of the Association of American Geographers, 69, No. 4, pp. 589-598.

KOLODKO, G. (1999): Fiscal Policy and Capital Formation in Transition Economies, Working paper, IMF, $48 \mathrm{pp}$.

LEFEBVRE, H. (1996/1967): Writings on Cities. Wiley-Blackwell, Oxford, 250 pp.

LEY, D. (1996): The New Middle Class and the Remaking of the Central City. Oxford University Press, New York, $383 \mathrm{pp}$.

LEY, D. (2003): Artists, Aestheticisation and the Field of Gentrification. Urban Studies, 40, No. 12, pp. 2527-2544. 
MAKAGON, D. (2010): Bring on the Shock Troops: Artists and Gentrification in the Popular Press, Communication and Critical/Cultural Studies, 7, No. 1, pp. 26-52.

MARCUSE, P. (1985): Gentrification, abandonment anddisplacement: connections, causes and policy responses in New York City. Journal of Urban and Contemporary Law, 28, pp. 195-240.

MARCUSE, P. (2009): From critical urban theory to the right to the city. City: Analysis of Urban Trends, Culture, Theory, Policy, Action, 13, No. 2, pp. 185-197.

MERTON, R.K. (1938): Social Structure and Anomie. American Sociological Review, 3, No. 5, pp. $672-682$.

MITCHELL, D. (2003): The Right to the City. Guilford Press, New York, 270 pp.

PRUIJT, H. (2004): Squatters in the Creative City: Rejoinder to Justus Uitermark. International Journal of Urban and Regional Research, 28, No. 3, pp. 699-705.

PURCELL, M. (2002): Excavating Lefebvre: The right to the city and its urban politics of the inhabitant. GeoJournal, 58, No. 2-3, pp. 99-108.

PURCELL, M. (2003): Citizenship and the right to the global city: reimagining the capitalist world order. International Journal of Urban and Regional Research, 27, No. 3, pp. 564-590.

RŮŽIČKA, V. (2006): Squaty a jejich revoluční tendence. Triton, Praha, 207 pp.

SHAW, K. (2006): The Place of Alternative Culture and the Politics of its Protection in Berlin, Amsterdam and Melbourne. Planning Theory and Practice, 6, No. 2, pp. 151-170.

SMITH, N. (1984): Uneven development: nature, capital and the production of space. Blackwell, Oxford, $219 \mathrm{pp}$.

SMITH, N. (1996): The New Urban Frontier: Gentrification and the revanchist city. Routledge, New York, $267 \mathrm{pp}$.

SMITH, N. (2002): New Globalism, New Urbanism: Gentrification a Global Urban Strategy. Antipode, 34, No. 3, pp. 434-457.

SÝKORA, L. (2008): Revolutionary change, evolutionary adaptation and new path dependencies: socialism, capitalism and transformations in urban spatial organizations. In: Strubelt, W., Gorzelak, G. (eds): City and Region. Papers in Honour of Jiř́i Musil. Budrich UniPress, Leverkusen Opladen, p. 283-295.

SÝKORA, L. (2009): Post-Socialist Cities. In: Kitchin, R., Thrift, N, (eds.): International Encyclopedia of Human Geography, 8, Elsevier, Oxford, p. 387-395.

SÝKORA, L., BOUZAROVSKI, S. (2012): Multiple transformations: conceptualising postcommunist urban transition. Urban Studies, 49, No. 1, pp. 43-60.

UITERMARK, J. (2004): The Co-optation of Squatters in Amsterdam and the Emergence of a Movement Meritocracy: A Critial Reply to Pruijt. International Journal of Urban and Regional Research, 28, No. 3, pp. 687-698.

VANEK, M. et al. (2002): Ostrůvky svobody. Kulturní a občanské aktivity mladé generace v 80. letech v Československu. Votobia, Praha, 350 pp.

WILLIAMSON, J. (1990): Latin American Adjustment: How Much Has Happened? Institute for International Economics, Washington, DC, $445 \mathrm{pp}$.

ZUKIN, S. (1982): Loft Living: Culture and Capital in Urban Change. Johns Hopkins University Press, Baltimore, $232 \mathrm{pp}$.

ZUKIN, S. (1998): Urban Lifestyles: Diversity and Standardisation in Spaces of Consumption. Urban Studies, 35, No. 5-6, pp. 825-839.

ZUKIN, S. (2010): Naked city: the death and life of authentic urban places. Oxford University Press, Oxford, $312 \mathrm{pp}$.

Shrnutí

\section{PROSTORY ALTERNATIVNÍ KULTURY V PRAZE V ČASE POLITICKO-EKONOMICKÝCH PROMĚN MĚSTA}

Autorka článku se zabývá pražskou alternativní kulturou z hlediska prostorů, ve kterých se tato kultura odehrává v rámci městského prostředí procházejícího významnými proměnami způsobenými změnou politicko-ekonomického kontextu české společnosti. Článek se zaměřuje 
na hlavní rysy, fungování a geografickou polohu prostorů, které byly pro účely alternativní kultury využívány $\mathrm{v}$ průběhu tři různých období - v době totalitního socialismu, $\mathrm{v}$ době postsocialistické transformace a v době současného neoliberálního kapitalismu. Autorka se zaměřuje především na vztahy mezi společenskou strukturou a prostorovými podmínkami, v nichž je alternativní kultura v daném kontextu provozována. Sledováním prostorů, které alternativní kultura na území Prahy využívala v průběhu měnících se režimů, se autorka snaží odhalit, zda v současné společnosti došlo ke skutečné demokratizaci a k toleranci vůči kulturní pluralitě, respektive k odstranění represivního přístupu, kterým se ve vztahu k alternativní kultuře vyznačoval minulý totalitní režim.

S odkazem na marxistickou urbánní teorii a na koncept „právo na město“ (right to the city) upozorňuje na to, že ve svobodné společnosti by měli mít všichni lidé právo užívat město a jeho zdroje $\mathrm{k}$ uspokojení svých kulturních potřeb a k provozování různých neziskových činností. Možnost provozovat tyto činnosti a kulturu by přitom neměla být podmíněna jejich potenciálem k vytváření ekonomického zisku. Autorka proto kriticky přezkoumává sociální struktury založené na současném socioekonomickém modelu z hlediska toho, jaké podmínky vytvář́ pro kulturní pluralitu. S pomocí empirických dat shromážděných během etnografického výzkumu pražských prostorů využívaných současnou alternativní kulturou autorka poukazuje na fakt, že ve vztahu k takto využívaným prostorům a ke kulturní pluralitě ve společnosti nadále přetrvávají represivní praktiky minulého režimu, které v kombinaci s dogmatickým pojetím neoliberálního kapitalismu omezují rozvoj občanské společnosti, otevřené demokracie a pestrého, živého, progresivního a vůči kulturní pluralitě inklusivního městského prostředí.

Autorka v článku věnuje pozornost proměnám v geografické poloze prostorů využívaných alternativní kulturou v rámci města (znázorněny pomocí tří map ze tří různých období), v typu užívaných nemovitostí a v podmínkách jejich užívání. Zatímco během bývalého totalitního režimu musely být prostory využívané alternativní kulturou utajované, a geografickou polohu těchto prostorů neurčovaly tržní síly, nýbrž represe totalitní ideologie, v demokratizované společnosti se již kulturní pluralita a prostory využívané alternativní kulturou stávají legitimní součástí městského prostředí. V Praze však podmínky vhodné pro kulturní pluralitu trvaly pouze během období turbulentní postsocialistické transformace, které autorka v článku vymezuje první dekádou po Sametové revoluci. Toto období se vyznačovalo zvýšenou tolerancí společnosti vůči novým alternativám, jež se dočasně koncentrovaly i v centru Prahy. Na přelomu tisíciletí začaly být alternativní kultury v centru ohroženy komercializací, ekonomickou konkurencí a nespoutaným městským rozvojem. Tlak trhu začal alternativní kulturu zatlačovat do bývalých industriálních zón procházejících časovým obdobím vymezeným dorovnáním rozdílu mezi potencionální a reálnou hodnotou příslušného pozemku (tzv. time-gap). Tato zóna se prodlužuje spolu se stagnací městského rozvoje, k níž v pražském kontextu došlo zejména po roce 2008 v důsledku globální ekonomické krize. Alternativní kultura provozovaná konformnějšími skupinami, jako jsou studenti, umělci, hudebníci nebo kreativní profesionálové, mohla $\mathrm{v}$ daných lokalitách výměnou za snížené nájemné a údržbářské činnosti setrvat déle, avšak její pobyt zůstal do budoucna i nadále časově omezen momentem obnovení rozvoje a ekonomického růstu. I konformnější provozovatelé alternativní kultury jsou takto nadále nuceni fungovat $\mathrm{v}$ nejistých a dočasných podmínkách a do budoucna lze očekávat jejich další odsun směrem na periferii. Oproti tomu alternativní kultura provozovaná rezistentními skupinami, jako jsou anarchisté, je celospolečensky ostrakizována a často tudíž není možné jí v prázdných a chátrajících prostorách využívat ani se souhlasem majitele. Její případné pokusy o neautorizované užívání těchto prostor bývají obvykle postihovány okamžitým násilným vystěhováním. Specifickým případem prostoru využívaného alternativní kulturou je hospůdka Parukářka, která i přes svou popularitu dodnes nezískala stavební povolení $\mathrm{v}$ důsledku spekulativních záměrů developerů, kteří v dané lokalitě staví.

Článek kriticky hodnotí také postoj různých provozovatelů alternativní kultury ke svému právu na město. Zatímco někteří se novým podmínkám i přes jejich nevýhodnost ochotně přizpůsobují a de facto tak asistují privátním rozvojovým zájmům, jiní jim i nadále aktivně vzdorují a spojují své síly s dalšími společenskými skupinami postiženými dogmatickým pojetím neoliberálního kapitalismu v soudobé české společnosti. Autorka dochází k poznatku, že toto dogmatické pojetí nového společenského řádu opět, podobně jako tomu bylo v případě režimu minulého, důmyslně eliminuje a marginalizuje alternativní kulturu. Tuto 
skutečnost autorka představuje jako přičinu i důsledek stále nedostatečně rozvinuté občanské společnosti, otevřené demokracie i kulturní plurality v soudobém Česku, jakož i nedostatku historických zkušeností českých obyvatel se socioekonomickými nerovnostmi v kapitalistické společnosti. Jako východisko z této situace vidí nápravná opatření vycházející z činnosti alternativních kultur samotných.

Obr. 1 - Prostory využívané alternativní kulturou v Praze během rané transformace. V legendě shora: soukromé byty, hospody, kulturní centra, Jazzová sekce, místa venkovních setkání.

Obr. 2 - Prostory využívané alternativní kulturou v socialistické Praze (70.-80. léta 20. stol.). V legendě shora: kluby, squaty, neoprávněně obydlené domy, Rádio Stalin, haly ČKD, tábořiště britských „sound systémư"v létě 1994.

Obr. 3 -Prostory alternativní kultury v kontextu neoliberálního urbanismu. V legendě shora: užívaná místa/prostory alternativní kultury a experimentování, neužívaná místa/prostory alternativní kultury a experimentování, užívaná místa rezistence, neužívaná místa rezistence, užívaná místa alternativní kultury a rezistence.

Authors' affiliation: Charles University in Prague, Faculty of Science, Dpt. of Social Geografy and Regional Development, Albertov 6, 128 43, Prague 2, Czechia; e-mail: mpixova@hotmail. com.

Initial submission, 29 August 2012; final acceptance 12 July 2013.

\section{Please cite this article as:}

PIXOVÁ, M. (2013): Spaces of alternative culture in Prague in a time of political-economic changes of the city. Geografie, 118, No. 3, pp. 221-242. 